\title{
Impact of Covid-19 on Several Industries in Context with the Sperm Bank Industry
}

Ashish Gujrathi *

Allied Market Research, Viman Nagar Pune Sainik Nagar, Somnath Nagar, Wadgaon Sheri, Pune, Maharashtra, India.

*Corresponding author: Ashish Gujrathi, Allied Market Research, Viman Nagar Pune Sainik Nagar, Somnath Nagar, Wadgaon Sheri, Pune, Maharashtra, India.

Received date: June 16, 2021; Accepted date: July 11, 2021; Published date: July 19, 2021

Citation: Ashish Gujrathi, (2021). Impact OF Covid-19 on Several Industries in Context with the Sperm Bank Industry. J Clinical Research and Reports, 8(4); DOI:10.31579/2690-1919/183

Copyright: () 2021 Ashish Gujrathi. This is an open access article distributed under the Creative Commons Attribution License, which permits unrestricted use, distribution, and reproduction in any medium, provided the original work is properly cited.

\begin{abstract}
COVID-19 is an infectious disease that originated in Hubei province of the Wuhan city in China in late December. The highly contagious disease, caused by a virus, severe acute respiratory syndrome coronavirus 2 (SARS-CoV2), is transmitted from humans to humans. After the first case in Wuhan, the disease rapidly spread to other parts of the globe. On March 11, 2020, the World Health Organization (WHO) made an assessment that COVID-19 can be characterized as a pandemic. Thus, social-distancing became an important measure to stop the spread of this disease. Various countries across the world adopted nationwide lockdown. This led to a completely new scenario for the world, where every business in each industry faced new challenges and witnessed new opportunities.
\end{abstract}

Keywords: covid-19; sperm bank industry; cryopreservation techniques; respiratory syndrome coronavirus; infertility treatment; artificial insemination
Impact of COVID-19 on several industries in context with the sperm bank industry

COVID-19 is an infectious disease that originated in Hubei province of the Wuhan city in China in late December. The highly contagious disease, caused by a virus, severe acute respiratory syndrome coronavirus 2 (SARS-CoV-2), is transmitted from humans to humans. After the first case in Wuhan, the disease rapidly spread to other parts of the globe. On March 11, 2020, the World Health Organization (WHO) made an assessment that COVID-19 can be characterized as a pandemic. Thus, social-distancing became an important measure to stop the spread of this disease. Various countries across the world adopted nationwide lockdown. This led to a completely new scenario for the world, where every business in each industry faced new challenges and witnessed new opportunities. Similarly, the sperm bank industry, a vital part of the healthcare sector, was hit in a deleterious manner. Before the outbreak, growth of the sperm bank industry was expected to show a gradual increase, owing to various factors such as innovations in cryopreservation techniques. Furthermore, emergence of fertility tourism, and increase in access to infertility treatment are the key factors that drive the growth of the market. However, the spread of coronavirus has led to unexpected changes in the sperm bank industry, thereby by negatively impacting the overall growth. 


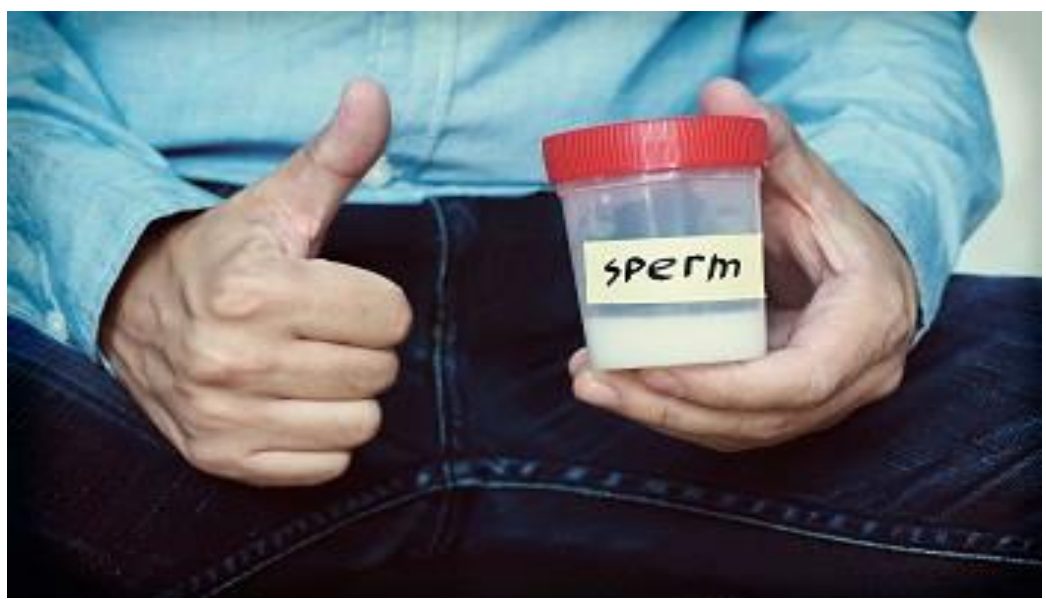

The spread of the virus led to major disruption in the beginning phase of the lockdown, wherein business-related restrictions were stringent, which, in turn, caused disruption of the supply chain, as logistics were compromised in every part of the world initially. Other changes included implementation of safety measures such as social distancing at work places, which resulted in dearth of human resources.

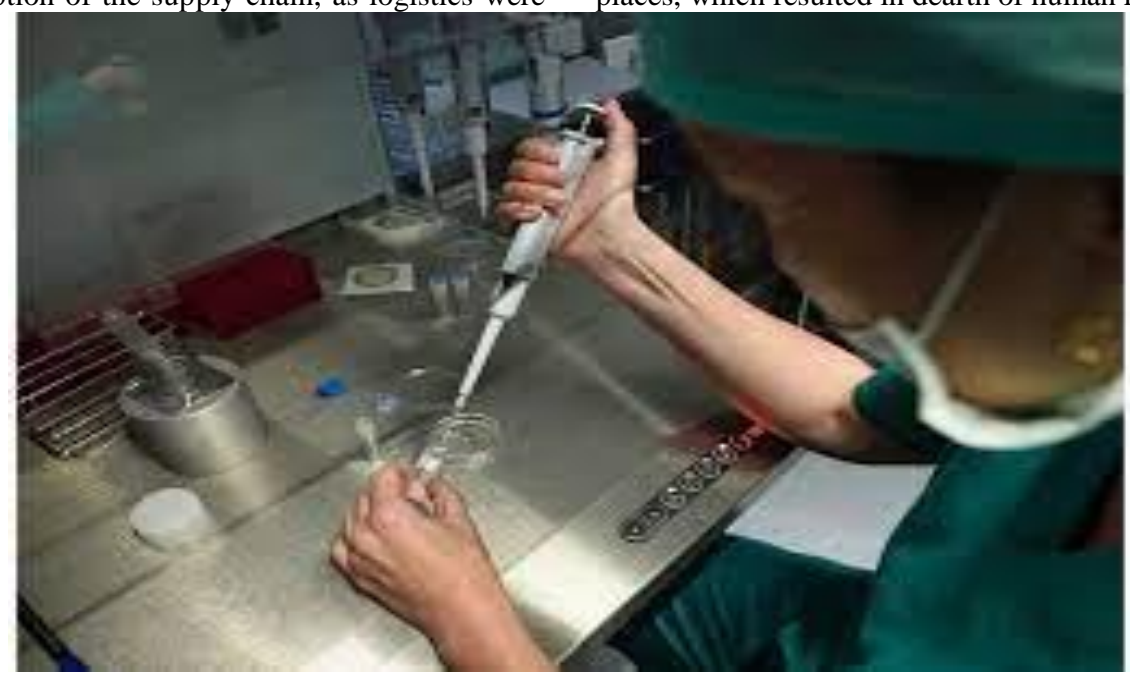

Impact of COVID-19 on several industries in context with the sperm bank industry

Sperm bank (semen bank or cryobank) is a specific repository that purchases and stores the sperms under scientifically controlled conditions to keep them viable for a longer period of time. These stored sperms are sold to clinics and hospitals across the globe for artificial insemination, which involves introduction of the sperm directly into the female's uterine cavity to fertilize the egg for the purpose of achieving pregnancy. Thus, sperms donated at the sperm banks help achieve pregnancy similar to the pregnancy achieved by sexual intercourse. However, sperm donors generally must fulfil specific requirement regarding age and medical history to donate their sperm. Likewise, numerous countries have laid down different rules and regulations for sperm bank donors. Therefore, favourable and supportive criteria for sperm donation is anticipated to have a positive impact on the growth of the sperm bank market over the next few years.

Pandemics have always had significant social and economic impacts to humanity over centuries. The COVID-19 pandemic has affected sperm bank and fertility clinics, due to shutdowns in various COVID-19 affected countries and rise in number of healthcare workers falling ill in the pandemic, which is why people were unable to come to sperm bank for donation and treatment. Furthermore, patients undergoing infertility treatment lost access to services and is happened due to lockdown in various countries. Hence, the outbreak of COVID-19 has disrupted from both supply side and demand side. The disease has forced a number of industries to shut their doors temporarily and led reproductive centers to severely limit their activities, including several sub-domains of health care including sperm bank industry. Furthermore, various threat and concerns regarding sperm donation, insemination treatment, and cryopreservation including, the detection of this COVID virus on male and female reproductive cell or tissue, contamination of semen sample during cryopreservation, transmission of infectious disease during the treatment negatively impacted the growth of the sperm bank industry.

Furthermore, decrease in number of sperm donation led to surge in shortage of sperm in various regions and delays in accessing insemination and IVF treatment hampers the growth of the sperm bank industry.

\begin{tabular}{|l|l|l|l|l|l|l|l|l|l|}
\hline & 2019 & 2020 & 2021 & 2022 & 2023 & 2024 & 2024 & 2026 & 2027 \\
\hline $\begin{array}{l}\text { Global } \\
\text { Market }\end{array}$ & $4,741.5$ & $3,409.1$ & $2,995.6$ & $3,218.2$ & $3,515.2$ & $3,874.8$ & $4,188.7$ & $4,519.2$ & $4,860.4$ \\
\hline
\end{tabular}

Table 1. Global Sperm Bank Market, 2019-2027 (\$Million) 


\section{Expectations from the sperm bank industry}

Many sperm banks are facing issues due to recession and COVID-19 shutdowns. Some sperm banks chose to remain open, while others chose to shut down. Around 50\% of sperm banks were shut down for around two months in 2020, while the other half operated under new state mitigation restrictions and lesser patient volumes. Furthermore, globally many sperm banks have implemented additional laboratory screening for SARS-CoV-2 (the viral agent causing COVID-19) on all donors. In addition to monitoring temperature, symptoms, and potential exposures, donors are anticipated to receive frequent and recurrent laboratory testing for the virus while participating in the program. In addition, this type of testing is not recommended or required by any regulatory or accrediting body, however many centers believe that these extra precautions are expected to help maintain a safe environment for staff, donors, and clients.

\section{Post COVID-19 scenario}

As nations are easing the lockdown restrictions, economy will still require time to stabilize. The sperm bank industry was one of the few businesses to get negatively impacted and possibly would take longest to recover.

Post COVID-19, landscape of sperm bank will bring about lot of changes in the way this business was traditionally performed, which include focus on hygiene \& personalized treatment, webinars, and telemedicine/tele consults.

Furthermore, key players operating in the sperm bank industry are anticipated to face new challenges related to different aspects. The scenario is expected to change upon resuming rescheduled appointments leading to sudden rise in number of IVF procedures and demand for IVF procedures. Similarly, decision making management of fertility clinics and sperm bank centers is anticipated to face challenges such as improvement of liquidity, management of working capital, and better management of expenditures. Pending fertility treatments are expected to be completed post COVID-19 pandemic. Such number of pending or suspended sperm collection procedures are expected to result into an exponential growth of the sperm bank industry along with recovery from COVID pandemic.

\section{Recent news in the sperm bank industry during the pandemic}

Industry players around the world are actively participating and taking efforts to remodel the business to fit in current situation of this pandemic. Many centers have arranged collaborative study to the detection of COVID-19 virus in the human semen.

For instance, in March 2021, Cryos International in collaboration with the Danish Hvidovre Hospital and Cooper Surgical, announced that the COVID-19 virus is not detected in human semen. Such announcement is expected to positively impact the sperm bank market endorsing the safety of sperm banking during this pandemic.

\section{References:}

1. https://www.alliedmarketresearch.com/sperm-bank-marketA10372

2. https://www.alliedmarketresearch.com/press-release/spermbank-market.html

3. https://www.globenewswire.com/en/newsrelease/2021/05/18/2231714/0/en/Sperm-Bank-Market-toGenerate-4-86-Billion-by-2027-Allied-Market-Research.html
This work is licensed under Creative Commons Attribution 4.0 License

To Submit Your Article Click Here: Submit Manuscript

DOI: $10.31579 / 2690-1919 / 183$

\author{
Ready to submit your research? Choose Auctores and benefit from: \\ * fast, convenient online submission \\ * rigorous peer review by experienced research in your field \\ * rapid publication on acceptance \\ * authors retain copyrights \\ * unique DOI for all articles \\ * immediate, unrestricted online access
}

At Auctores, research is always in progress.

Learn more auctoresonline.org/journals/journal-of-clinical-research-andreports 